\title{
The Games of the New Emerging Forces (GANEFO) 1963: The Olympics of the Left
}

\author{
Retno Mustikawati
}

\begin{abstract}
When The International Olympics Committee (IOC) required that sports had to be separated from political elements, President Sukarno actually initiated the Games of New Emerging Forces (GANEFO) in 1963in Indonesia, which based on the sports and political agenda. Sukarno considered that the Olympics was a sport event that channeled the interests of neo-colonialism and imperialism. So, GANEFO was based more on solidarity between the participating countries which consists of non-imperialist, socialist countries, which marked GANEFO famous by calling it the Olympics of the Left. Sukarno's conception of dividing the world into two, one was New Emerging Forces (NEFO) which consisted of progressive states, which he initiated in 1961 as a negation of The Old Established Forces (OLDEFO) which consisted of Imperialist-colonialist countries, then initiated the plan to organize GANEFO in 1963. Indonesia as the initiator plays an important role on this challenge for the International Olympic Committee (IOC). Criticism from the world and the exclusion of Indonesia from the IOC became a risk taken by Sukarno for the implementation of GANEFO. This paper aims to find out why Sukarno chose to take the risk of organizing GANEFO, how was it establish, and why was it establish, and the impact to Indonesian people in the eyes of the world.
\end{abstract}

Index Terms-GANEFO, NEFO \& OLDEFO, Sukarno.

\section{INTRODUCTION}

President Sukarno classified the Asian, African, Latin American and European socialist countries into NEFO as a counter to the old established forces (the United States and Western Europe) called The OLDEFO. Sukarno first introduced the concept of NEFO and OLDEFO at the NonAligned Movement Conference in Belgrad, Yugolslavia, September 1-6, 1961. [1], Following the concept of the 'Third World' - in contrast to the Western and Eastern Bloc, respectively, the 'First and Second World' - their policy was also coined Third Worldist policy. One of the main actors of this Third Worldist policy was the Indonesian President Sukarno, who had proclaimed Indonesian independence in 1945 and led the country until his removal from office in 1967. He was highly ambitious about his own role and the role of his country in the Non-Aligned Movement, creating his own political vision to gain a leading position [2].

According to Sukarno, the two groups were the two giant opposing blocs in the world that contradicted each other which will eventually emerge a new world order NEFO which will replace the old world order OLDEFO [3]. NEFO

Manuscript received November 26, 2019; revised Feburay 12, 2020. This work was supported in part by Shanghai University, P.R.China, under Grant of the Chinese Scholarship Council.

Retno Mustikawati is with College of Liberal Arts, Shanghai University, Department of Global Studies, 99 Shangda Road Baoshan District, Shanghai, China (e-mail: retnomustika7@gmail.com). was a term for new forces that were growing, forces of independence and justice, while OLDEFO was a term for the powers that have been established.

Sukarno stated that OLDEFO always threatened the world security, because OLDEFO states always wanted to rule the NEFO states [1]. He then embarked on his quest to form the New World body as a United Nation rival through the Conference of the New Emerging Forces (CONEFO) which aimed at the newly independent countries of Asia, Africa, Latin America and European socialist countries.

One strategy to fill his political vision of the competing forces was to create a platform for the NEFO to meet and interact, yet not in a formal political context, but rather on the personal level, especially among young people [2]. Hence, Sukarno found the place to be the patform for the youths to interact, namely The Games of the New Emerging Forces (GANEFO).

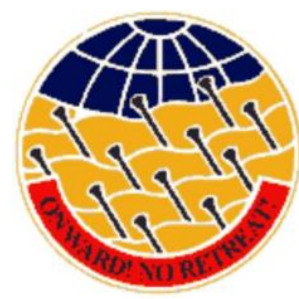

Fig. 1. GANEFO I logo (reprografi-WordPress.com).

President Sukarno appointed Maladi, the Sports Minister as chairman of the organizing of Ganefo. Twelve countries were invited to the Ganefo Preparatory Conference in Jakarta on April 27-29. Only ten countries were present (Cambodia, China, Guinea, Indonesia, Iraq, Pakistan, Mali, North Vietnam, the United Arab Republic [Egypt and Syria], and the Soviet Union). Ceylon (Sri Lanka) and Yugoslavia only sent observers. Nevertheless, the Ganefo logo [Fig. 1] was still made with 12 flagpoles, written with the motto, "Onward, No Retreat!"

GANEFO often served as an example of the entanglement of sport, Cold War politics and the Non-Aligned Movement in the 1960s [2]. In 1963, the foundation of the GANEFO thus had a strong link to the political agenda of the Indonesian President and his worldview. Yet, there were also some other factors which influenced the creation of GANEFO: first, there was the confrontation between Indonesia and the IOC; second, the interest of the Republic of China in creating sport games outside of the IOC; and third, the political awakening of the decolonizing countries mainly in Asia and Africa [2].

Twelve days of colourful and friendly contests, which caught worldwide attention, marked the New Emerging Forces (GANEFO) which started on November 10, and came 
to an end on November 22. In spite of a sudden downpour the final day saw a cheering crowd of 150.000 on hand to watch the parade of 2200 athletes from Asian, African, Latin America and European countries while national flags flew amidst the glow of myriad of floodlights. [Fig. 2] The keynote of the parade- and GANEFO itself -was to be found in one of the huge slogans that draped the grandstand in the main stadium of the Gelora Bung Karno sports complex [2], the enormous 10 million dollar sport complex which had been constructed with Soviet aid [4]. "Onward, No Retreat!"

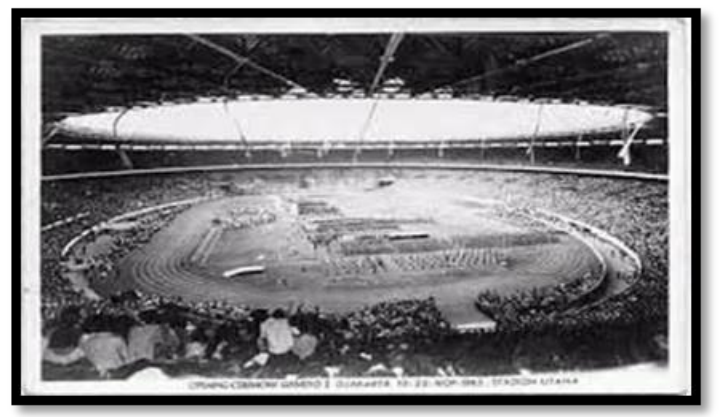

Fig. 2. Opening ceremony of GANEFO 1963 (www.delcampe.net).

GANEFO was held when Indonesia was in a period of Guided Democracy, at which time Indonesia's foreign policy conception was known as the Beacon Politics, which basically placed Indonesia at the center of the developing countries. Physical development in the country occurred on a large scale without any social control which caused a lot of disagreement because Sukarno's actions were deemed inappropriate to see the Indonesian economy was in downturn at that time.

\section{THE ORIGINS}

\section{A. In Beacon Politics}

Towards the end of the 1950s the Indonesian economy was in a downturn situation, inflation and scarcity of goods are common in the country. The government were trying to improve the situation, but the results did not show a significant progress. In the worst economic condition, President Sukarno actually submitted a proposal to the AGF to host the 4th Asian Games, in 1958.

Not only once did Indonesia volunteered to host the Asian Games. The effort had even begun since the first Asian Games in India in 1951. At that time the Asian Games Federation (AGF) rejected Indonesia's proposal to host the second Asian Games. The second proposal was again submitted to the AGF session which coincided with the second Asian Games in 1954 in the Philippines. In addition to economic problems, AGF considers Indonesia's political and security conditions to be less conducive.

At that time Jakarta was not yet a metropolitan and did not yet have sports infrastructure or other supporting accommodations such as hotels and convenient transportation facilities. Even so, Indonesia has one guarantee that is expected to convince the AGF: payment of Japanese warfare for development. It is likely that this guarantee will then be enough to convince AGF members, to make Jakarta the host of the 4th Asian Games.

When the nuclear crisis in the 1960s, it was the first step for Indonesia to make itself a beacon in global conflict by bringing the issues of world peace and the finalisation of sovereignty in the Asian-African sphere to the forefront of international debate [5].

The implementation of the First Games of the New Emerging Forces in Jakarta provided the Sukarno administration with the opportunity to realize the targets of the previous Asian Games. Thus, the event left behind the regional scope of the Asian Games and became a global project with a strong link to the Non-Aligned Movement [6]. These ideas were supported by the Soviet Union and PRC in diplomacy, politics, economics and military matters which helped Indonesia to promote the Bandung Spirit to Asian-African countries in their struggles to break free of colonialism, in states such as the Congo, Algeria and Vietnam [2]. Those conceptions not only occurred in the domains of diplomacy and politics, but also related to the blue-print of economic cooperation, cultural exchange and also in the domain of sports (for example, GANEFO, the Games of New Emerging Forces) in 1963 [7].

The lobbying process finally met with certainty, Indonesia officially became the organizer of the 4th AG whose announcement came out on May 23, 1958, when the Asian Games the 3rd took place in Tokyo [6].

\section{B. Gelora Bung Karno Stadium (Sukarno Sport Complex)}

After the Indonesian proposal was officially accepted as the organizer of the 4th Asian Games, Indonesia had only four years to carry out infrastructure development to hold a sports event in Jakarta. Developments in Indonesia received aid in the form of financial capital and infrastructure technology from the Soviet Union and the PRC [8]. China's full support of GANEFO included political, organizational and financial concerns [6]. The mobilization of all national potentials was needed, because the costs required to organize GANEFO were very large. The action was carried out by collecting funds from all Indonesian people. In addition, the People's Republic of China donated 18 million dollars to transport all GANEFO delegates [2].

Indonesia also submitted a proposal to the Soviet Union to borrow funds amounting to 12.5 million US dollars to build sports facilities and infrastructure, including the main stadium, swimming pool, sports hall, boarding house / athlete and other buildings [1]. Sukarno him self designed the Gelora Bung Karno Stadium [Fig. 3], an oval-shaped sports arena and connected to each other, with a capacity of 100,000 people [9]. This stadium became the biggest stadium in Indonesia.

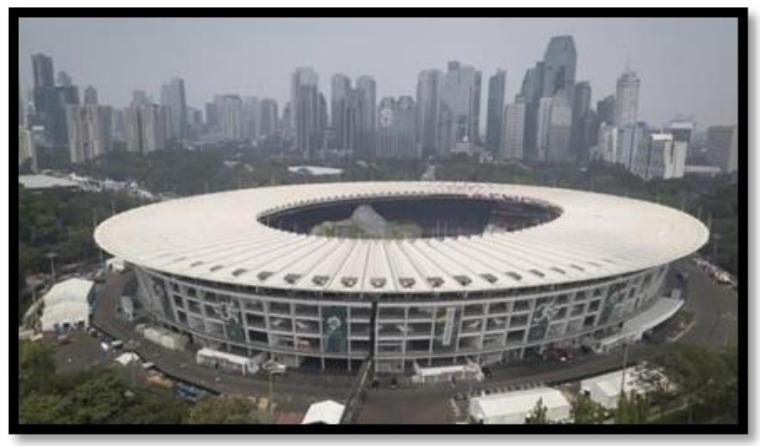

Fig. 3. Gelora Bung Karno Stadium 1962 (antaranews.com). 
Precisely on February 8, Sukarno inaugurated Gelora Bung Karno Main Stadium, which was the result of Indonesia's cooperation with the Soviet Union in financial and architectural matters, and was proven by the Soviet Foreign Minister A.I. Mikojan came to Indonesia to inaugurate it [10].

\section{Conflict of Asian Games 1962}

The conflict between Indonesia and the IOC was going back to the politicization of the Fourth Asian Games, which took place in Jakarta in 1962 [8]. The Indonesian government made a policy to improve the dignity of the nation in the international world, namely making Indonesia as the fourth organizer of the Asian Games on August 24-September 4, 1962 in Jakarta. President Sukarno wanted to organize the 4th Asian Games in 1962 not only as a sporting event but also as a cultural festival. On August 24, 1962, President Sukarno officially opened Asian Games IV in Jakarta [Fig. 4].

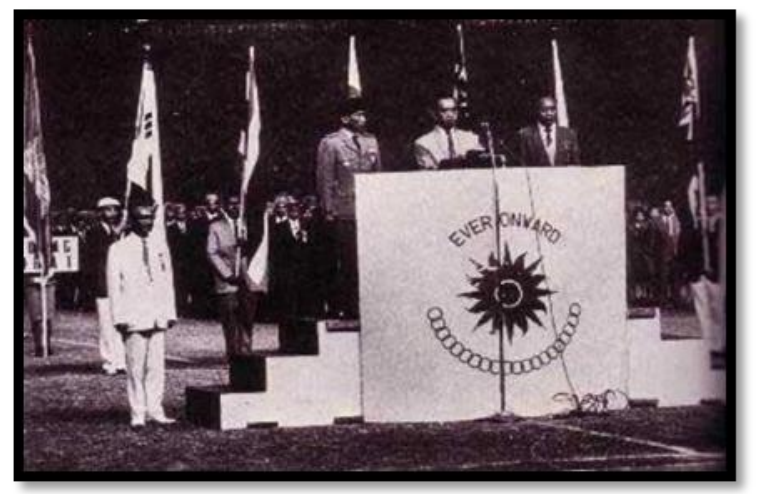

Fig. 4. Asian games 1962, Jakarta (olahraga.kompas.com).

When Indonesia was awarded the Asian Games in 1958, several initiatives started to secure a successful hosting of the event. On the one hand, the idea of success included following the motto of the Asian Games 'Ever onward'by reaching greater cooperation and solidarity among the Asian nations, as well as by outscoring the Western countries and their organizations (like the IOC), on the other hand, the focus lay on the development of Indonesia into a leading country for the Non-Aligned Movement [2].

On August 28, 1962, taking place at the Bali Room Hotel Indonesia, the II session of the congress of VII Asian Games Federation (AGF) took place [4]. At the time, Indonesia, after having invited various attend including Israel and Nationalist China, "failed to issue visas" to athletes of these latter two countries [1].

The reason Israel was not invited was because it had practiced colonialism with Palestinians. In addition, Indonesia also did not have diplomatic relations with Israel. Taiwan was not invited because Indonesia only recognized Taiwan as a part of the province of People's Republic of China [5]. The Indian Vice President of the Asian Games Federation, Sondhi, chided the Indonesians for allowing political considerations to mar the Games. These remarks sparked a demonstration against the Indian Embassy in Jakarta. In the end, Mr.Sondhi had to make a hasty departure from Indonesia as persona non grata [1].

Officially, Sukarno waited until the opening ceremonies to publicly ban Taiwan. Emergency AGF meetings were held and G. D. Sondhi, IOC-friendly AGF member, convinced the
IOC executive board to withdraw support of the Games. When news of the decision became public, riots directed at Sondi broke out in Jakarta and he fled, but he continued to lobby the IOC for suspension of Indonesian membership [5].

As the result of all this, the IOC meeting in Lausanne on February 7, 1963, suspended Indonesia from the Olympic Games on the basis that politics had been allowed to enter the non-political field of sports during the Asian Games [11]

\section{Indonesia and IOC Relationship}

The absence of Taiwan and Israel caused problems for the Government of Indonesia. The IOC was sentenced by the removal of Indonesia from IOC membership and the non-recognition of the holding of the 1962 Asian Games.

President Sukarno was disappointed with the IOC's decision to sentence Indonesia. He tried to give an explanation to the IOC by sending Indonesia representatives of the Government, Sri Pakualam (KOI/ Komite Olimpiade Indonesia (Indonesia Olympiade Committee) Chair), Col. D. Ashari (General Secretary of the Organizing Committee Asian Games) and Soelaiman (Representative of the Ministry of Foreign Affairs). All three were sent to several countries in Asia, Africa, Latin America and Europe. The tasks of the delegates, namely 1).Preventing Shondi's efforts in the IOC to exclude Indonesia from the Olympic Games, 2). Influence participating countries of the Asian Games so that countries do not comply with International Assosiation of Athletics Federation (IAAF) decisions regarding the validity of the Asian Games, 3). Securing the results and name of the Asian Games, and 4). Held up approach with several Asian and African countries regarding The Games Emerging Forces in Jakarta year 1963 [5].

The penalties given by the IOC without prior hear the Indonesian Government's explanation had made Sukarno stated that the IOC had insulted Indonesia with the punishment issued and the IOC had become a tool of the people imperialism to dominate sports affairs.

Indonesia was furious at IOC. Its anger was directed particularly toward the American president of the IOC, Avery Brundage. A few days later, the idea of GANEFO, Indonesia's anwer to the Olympics-was announced [1].

In a cable sent August 11, 1962, from Avery Brundage to the Taiwan member of the AGF, Gunsun Hoh, Brundage stated that the "IOC has no connection whatsoever with Djakarta" [5].

The treatment of the IOC in Indonesia was different from its attitude toward the events that had occurred in other countries. West German and East German events discussing the formation of a team Germany Olympic, and to North Korea and South Korea on forming a team of Korea Olympic. Both countries were given the opportunity to express their views and attitudes respectively to the Executive Board of the IOC. Different attitudes of the IOC had taken action discriminatory and unfair against Indonesia.

Besides Indonesia, the other main initiator in the realization of GANEFO was the Republic of China, which demonstrated a similar confrontational attitude towards the IOC.The Chinese showed an immense interest in the project of GANEFO since they were not part of the IOC, but rather already in opposition with the entire Western and Communist World [11]. 


\section{PREPARATORY}

The Indonesian government then held the GANEFO I Preparatory Conference in Jakarta. The GANEFO Preparatory Conference was held on April 27-29, 1963. The conference invited 17 countries, but in the implementation it was attended by 12 countries, including the Kingdom of Cambodia, People's Republic of China, Republic of Ghana, Republic of Indonesia, Republic of Iraq, Republic of Mali, Republic of Pakistan, Democratic Republic of Vietnam, Republic of Arab Union, Republic of Soviet Socialist Union.

While Sri Lanka, the Federal Republic of Yugoslavia Socialist, as an observer country [2].

The Preparatory conference was held behind the closed doors, but documents later published on the conference result indicated that a number of differing views emerged on the political nature of the Games [12]. GANEFO's preparatory conference resulted in a decision that had been mutually agreed upon by the participating countries. These decisions include; 1). GANEFO was based on the spirit of the Asian-African Conference in Bandung and the Olympic aspirations. 2). The Ganefo will be held for the first time in mid November 1963 in Jakarta; and 3). GANEFO was celebrated every four years.

The Indonesian government issued a policy of mobilizing national potential for the success of GANEFO. President Sukarno formed the GANEFO National Committee. The GANEFO National Committee had the task to prepare and carry out the first Ganefo in Jakarta at the end of 1963, which includes the following efforts; 1). The maximum mobilization of GANEFO participating countries; 2). Mobilizing all national potential to succeed GANEFO; 3 ). Organizing a GANEFO celebration; 4). Formation of the strongest Indonesian National Team for GANEFO; 5). Budget planning for GANEFO [5].

In order to make the Games a successful sports competition as well as a useful arena for political maneuvers, it was most important for Indonesia that as large a number of countries as possible. President Sukarno made it possible to circumvent the problems posed to certain countries by the threats of expulsion made by International sports federations by supplying a deft definition of "New Emerging Forces."He explained that New Emerging Forces were those forces born of the struggle, or which are still struggling, against colonialism and imperialism created by the Old Established Forces. Among the New Emerging Forces are the countries of Asia, Africa, Latin America and all the socialist countries [1].

The GANEFO participant mobilization committee finally succeeded in inviting friendly countries to take part in GANEFO. Countries that were successfully invited to the holding of the 1st GANEFO as many as 51 countries spread over four continents. The countries that participated included; Continent Asia (Afghanistan, Burma, Cambodia, Sri Lanka, North Korea, Indonesia, Iraq, Japan, Laos, Lebanon, Mongolia, Pakistan, Palestine, China, Philippines, Saudi Arabia, Syria, Thailand and North Vietnam), Continent Africa (Algiers, Guinea, Morocco, Nigeria, Mali, Senegal, Somalia, Tunisia, United Arab Republic), European Continents (Alabania, Belgium, Bulgaria, Czechoslovakia, Finland, France, East Germany, Hungary, Italy, The Netherlands, Poland, Romania, the Soviet Union and
Yugoslovakia), and the Americas (Argentina, Bolivia, Brazil, Chile, Cuba, Dominica, Mexico, Uruguay and Venezuela).

\section{THE BRAND NEW SPIRIT}

"We value medals but we value friendship more." This not only was the byword spoken in Indonesian, Chinese, Japanese, English, French or Spanish in Jakarta but also a guide to action on the field [5]. The presence of representatives from all the Communist countries without exception at GANEFO could also be interpreted as significant in this day of the Sino-Soviet split [4]

Sports officials and athletes from various countries also are unanimous in their preise of GANEFO for reflecting the spirit of equality and democracy, brotherhood and mutual respect among athletes of different countries [5]. Unlike the international Olympics which are based on pure competition to find champions, GANEFO was based on sports to strengthen brotherhood and solidarity. Before GANEFO was opened, Sukarno invited Indonesian contingents to the State palace. There he stressed, the task of Indonesian athletes was not only to show their abilities in the field of sports, but also to build friendships with athletes / participants from other countries [4].

Officials of GANEFO's organizing and competitions committees disclosed that, in contrast to the imperialist-controlled Olympic Games, GANEFO had no discriminatory rules and regulations. It has drawn up a new competition rules by taking into the consideration the opinion of the participating nations in the spirit of democratic consultations [5].

\section{CONCLUSION}

The concept of Beacon Politics was run by President Sukarno that aimed to make Indonesia as a beacon, a lighthouse that lighted the way for the New Emerging Forces. The politics was Sukarno's ambitious politics, by constructing of mega projects, the iconic buildings that require a very large cost, which began to be realized when Indonesia was accepted as the organizer of the Asian Games $\mathrm{IV}$, as proof of the international world, that Indonesia had the competitiveness and proper dignity.

The implementation of GANEFO that was triggered by Indonesia's conflict with the International Olympics Committee (IOC) resulted Indonesia recived suspension not to join any International sport events, since Indonesia failed in issuing visas to Taiwan and Israeli contingents during the Asian Games IV. The IOC thought that sporting events must be separated from political affairs, while in Sukarno view, the sports could not be separated from political affairs, and then initiated the GANEFO which purpose was clear to hold sports events that were integrated with political affairs.

From the number of participants were reaching 51 countries, had made this event was no less prestigious than the Olympics under the IOC. Hence, GANEFO was projected as the competitor of the Olympics, which then famous as the Olympics of the left.

The Indonesian delegation at the GANEFO preparatory conference also underlined the importance of fighting the 
international olympiad which was in fact became an instrument of imperialism. As IOC said that sports must be separated from politics, but in reality, they only had non-sosialist states, that was, countries that did not want to fight the neo-colonialism and imperialism . Indonesia had put forward honestly, that sports was something that was always related to politics. Indonesia put forward a proposal to combine sports and politics, and carried out the Games of New Emerging Forces-GANEFO for NEFO against OLDEFO.

Incessant influence from the Soviet Union and China invited criticism. Aside the Soviets had an interest in gathering of their strength in embracing nations, especially in Asia and Africa, against the western bloc, Indonesia at that time was so dilemmatic. The domestic economy was being destroyed, but on the other hand, Indonesia, together with the People's Republic of China as the pioneer of the Third World,took the opportunity through GANEFO to be the leading countries among the Third World.

\section{CONFLICT OF INTEREST}

The author declares no conflict of interest.

\section{AUTHOR CONTRIBUTIONS}

Retno Mustikawati is a PhD Candidate at Shanghai University, P.R. China, Department of Global Studies, majoring in History. A single author for this paper, she conducted the research, analyzed the data, wrote the paper. The research is a part of the fulfillment for her $\mathrm{PhD}$ research.

\section{ACKNOWLEDGMENT}

I would like to thank to Professor Guo Changgang, my supervisor at Shanghai University, P.R. China, Department of Global Studies, and to Chinese Government for financial support through Chinese Scholarship Council to pursue my $\mathrm{PhD}$.

\section{REFERENCES}

[1] Z. R. Nababan, "The Games of the New Emerging Forces (Ganefo) as a form of Indonesian resistance to imperialism in," Journal of State University, pp. 8-13, 2016.
[2] F. Trotier, "The legacy of the games of the new emerging forces and Indonesia's relationship with the International Olympic Committee,' The International Journal of the History of Sport, pp. 1-8, 2017.

[3] Suhaemi. Ganefo as political tool on guided democracy. Thesis Abstract, Indonesia University. [Online]. Available: http://lib.ui.ac.id/opac/themes/libri2/detail.jsp?id=20157055\&lokasi=1 okal

[4] First GANEFO Comes through with Flying Colours. (November 29 1963). Peking Review. [Online]. 48. pp. 18-19. Available: https://www.marxists.org/subject/china/peking-review/1963/PR196348.pdf

[5] E. T. Parker, "GANEFO I: Sports and politics in Djakarta," Rand.org, pp. 1-13, July 1964.

[6] H. K. Wibisono, S.AP, M.AP, Indonesia's Foreign Politics 1955-1965 Between Decolonisation and Beacon Politics, pp. 9-10.

[7] R. Geoffrey, The Soviet Union in World Politics Coexistence: Revolution and Cold War, 1945-1991, London and New York: Routledge, Taylor and Francis Group, 1999.

[8] K. R. Adriyan, "Indonesia's diplomacy instrument 1962-1966," Master Thesis, History Study Program, Sanata Dharma University Yogyakarta, pp. 13-21, 2019.

[9] R. Lutan, "Pembelajaran dan Strategi pendidikan Penjaskes," Jakarta Depdikbud-Dikdasmen, p. 16, 1998.

[10] A. Rahayu, "The sport event Asian games IV 1962 in Jakarta: Motivation and achievement," Master Thesis, Department of History, Faculty of Culture, Indonesia University, p. 81, 2012.

[11] H. Shuman and Amanda, "The politics of socialist athletics in the People's Republic of China, 1949-1966," UC Santa Cruz Electronic Theses and Dissertations, pp. 297-313, December 2014

[12] Komite Nasional Ganefo, "Documents on the preparatory conference for the Ganefo held in Djakarta 28and 29th April 1963," Jakarta: Documents, pp. 8-10, 1963.

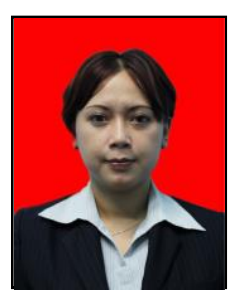

Retno Mustikawati is a PhD candidate at the College of Liberal Arts, Department of Global Studies, Shanghai University, P.R. China, in the major of history, with a master degree in 2010 in the Department of Cinema Studies, Faculty of Film, Television and Multimedia, Korean National University of Arts, South Korea.

She is also an academician in her home country, she teaches in the Faculty of Film and Television, Indonesia Institute of the Arts, Yogyakarta, Indonesia. Her current research about the global sixties, is her $\mathrm{PhD}$ dissertation unde the supervision of Professor Guo Changgang, at Department of Global Studies, Shanghai University, P. R. China. She is interested in the research fields of theories and history, post colonialism history, visual culture, and filmology. 